Discussion

Papers

\title{
An Early Warning System to Predict the House Price Bubbles
}


Opinions expressed in this paper are those of the author(s) and do not necessarily reflect views of the institute.

IMPRESSUM

(C) DIW Berlin, 2011

DIW Berlin

German Institute for Economic Research

Mohrenstr. 58

10117 Berlin

Tel. $+49(30) 89789-0$

Fax +49 (30) $89789-200$

http://www.diw.de

ISSN print edition $1433-0210$

ISSN electronic edition 1619-4535

Papers can be downloaded free of charge from the DIW Berlin website:

http://www.diw.de/discussionpapers

Discussion Papers of DIW Berlin are indexed in RePEc and SSRN:

http://ideas.repec.org/s/diw/diwwpp.html

http://www.ssrn.com/link/DIW-Berlin-German-Inst-Econ-Res.html 


\title{
An early warning system to predict the house price bubbles*
}

\author{
Christian Dreger Konstantin A. Kholodilin
}

July 21, 2011

\begin{abstract}
In this paper, we construct the country-specific chronologies of the house price bubbles for 12 OECD countries over the period 1969:Q12010:Q2. These chronologies are obtained using a combination of a fundamental and a filter approaches. The resulting speculative bubble chronology is the one that provides the highest concordance between these two techniques. In addition, we suggest an early warning system based on three alternative approaches: signalling approach, logit and probit models. It is shown that the latter two models allow much more accurate predictions of the house price bubbles than the signalling approach. The prediction accuracy of the logit and probit models is high enough to make them useful in forecasting the future speculative bubbles in housing market. Thus, our method can be used by the policymakers in their attempts to timely detect the house price bubbles and attenuate their devastating effects on the domestic and world economy.
\end{abstract}

Keywords: House prices; early warning system; OECD countries.

JEL classification: C25; C33; E32; E37.

*DIW Berlin, Mohrenstraße 58, 10117 Berlin, Germany, cdreger@diw.de and kkholodilin@diw.de. Financial support from the German Ministry of Finance is gratefully acknowledged. 


\section{Contents}

1 Introduction 1

2 Bubble chronology 5

3 Prediction of bubbles $\quad 7$

3.1 Signalling approach . . . . . . . . . . . . . . 7

3.2 Logit/probit approach . . . . . . . . . . . . . 8

4 Evaluating the accuracy of predicting the bubbles 9

5 Conclusion $\quad 9$

$\begin{array}{ll}\text { References } & 10\end{array}$

$\begin{array}{ll}\text { Appendix } & 13\end{array}$ 


\section{List of Tables}

1 Data description .................. . . 13

2 Optimal thresholds for signalling approach . . . . . . . . . . 14

3 Chronology of the speculative bubbles of house prices . . . . . 15

4 Descriptive statistics of the house price speculative bubbles . . 16

5 Prediction accuracy of the alternative models . . . . . . . . 16

\section{List of Figures}

1 Chronology of the house price bubbles . . . . . . . . . . 17

2 House price bubbles vs. bubble prediction by signalling approach 18

3 House price bubbles vs. bubble prediction by logit approach . 19

4 House price bubbles vs. bubble prediction by probit approach 20 
The past decade has proved again that the phrase "safe as houses" is a nonsense. Property will always be volatile - and financial crises will always be destructive. The main aim for policymakers must be to sever the connection between the two.

Andrew Palmer, The Economist March 5th 2011

\section{Introduction}

The striking role played by housing markets in the recent financial crisis has demonstrated that shocks in the housing sector can exert huge effects on real economic activity, in particular through their impact on private consumption and residential investment (Goodhart and Hofmann (2008)). Housing loans constitute the largest liability of households and account for a large proportion of bank lending. Especially in the Anglosaxon countries, in Spain, and some of the new EU member states, house prices increased tremendously in the pre-crisis period. The bursting of these house price bubbles has triggered massive production losses and raised serious doubts about the sustainability of the growth model in these states. In other countries like Germany, house prices did not accelerate at all. To the extent that the development of house prices is not equal across countries, they may constitute a source for business cycle divergence and can limit the prospects of a common monetary policy in the euro area. Housing markets are therefore highly relevant for the appropriate policy design.

Real house price dynamics depend on institutional features and macroeconomic and demographic conditions, most notably disposable income, the housing stock, inflation, interest rates, bank credit, changes in equity prices, population growth, see Muellbauer and Murphy (2008) and Kholodilin et al. (2010) for recent analyses. Lower interest rates decrease the opportunity cost of capital invested in housing, reduce the servicing cost of mortgage credit and raise the present value of future household earnings. The feedback from 
property prices to credit growth is stronger in countries with more deregulated mortgage markets, see Tsatsaronis and Zhu (2004). For example, borrowing costs exert a negative effect on real house changes in US regions, see Holly et al. (2010). Although house prices are usually driven by national forces, international components might be relevant in some cases. For instance, the evolution of real house prices in London is linked to New York and other financial centers (Holly et al. (2010)).

In addition, strong monetary growth over the recent years may have supported the emergence of house price bubbles, although the evidence is less clearcut on this point, even if international spillovers are acknowledged (Dreger and Wolters (2009)). A rise in liquidity affects the quantity and marginal utility of money holdings relative to housing and other assets. To restore equilibrium a rebalancing of the liquidity-asset ratio compatible with optimal portfolio allocation is required (Congdon (2005)). The adjustment process triggers higher housing demand and subsequent price increases. According to Adrian and Shin (2008), this effect is amplified through the procyclical balance-sheet management of financial intermediaries. The leverage, i.e., the ratio of total assets to equity is raised during house price booms and reduced in downturns. In addition, the relatively low and stable inflation environment reduced risk premia and might have led to higher financial instability, that is, excess credit pressures and additional leverage (Borio and Lowe (2002)).

Real house prices affect private consumption through a housing wealth and a collateral channel, see Case et al. (2005) and Dreger and Reimers (2009). An increase in housing wealth will raise consumption, due to its impact on expected lifetime income. Consumption expenditures can be shifted upwards without violating budget constraints. However, the effects on housing wealth are not obvious. A permanent increase in house prices could have a positive effect for homeowners, but there is also a negative effect on tenants who have to pay higher rents, and on prospective first-time buyers who have to save more for their intended house purchase, see Poterba (2000) and Goodhart and Hofmann (2008). In addition, increases in the value of owner-occupied housing do not foster the ability of a household to consume more of other goods and services unless that household is willing to realize the increased value, for example, by moving into a less expensive flat. Many households are not expected to do that, including those who intend to leave their homes as bequests. A positive impact of house prices on housing wealth implies that the winners win more than the losers lose. This is more likely 
to occur if would-be homeowners interpret a house price acceleration as evidence that they may earn future capital gains if they step into the real estate market. Such attitudes may be encouraged by lending institutions in highly competitive and deregulated mortgage markets.

Besides their effect on housing wealth, there is also a collateral effect of house prices, as houses are widely used as a security for loans, see Aoki et al. (2004) and Muellbauer (2008). Collateral effects dramatically improve the response of aggregate demand to house price shocks (Iacoviello (2005)). Households tend to borrow or lend to smooth consumption over time. If liquidity constraints exist, access to credit will be restricted. In periods of rising house prices, however, the value of the collateral the household can offer to banks is higher. Banks become less reluctant to increase their loans. Because of deregulation in mortgage markets, it has become easier and less expensive for consumers to borrow against housing collateral to finance extra consumption (Iacoviello and Neri (2010)). The amplification mechanism due to the increase in borrowing capacity is captured by the financial accelerator, see Bernanke et al. (1999) for the concept. This collateral-based accelerator tends to be higher in more deregulated financial markets, as financial innovation has increased the availability of funds for credit-constrained agents (Goodhart and Hofmann (2008)). Asymmetries are likely, as the effects of shocks to money and credit on house prices seem to be stronger when house prices are booming then otherwise.

Furthermore, housing markets have an impact on the transmission of monetary policy (IMF (2008)). In countries with more flexible mortgage rates and higher loan-to-value ratios, i.e., the ratios between the mortgage amount and the value of the property, the response of private consumption and residential investment to monetary policy shocks is amplified (Calza et al. (2009)). However, the relationship is not unidirectional, as housing wealth also affects money demand, see Dreger and Wolters (2009) and Setzer et al. (2010), among others. There is also evidence that idiosyncratic house price developments have been a major source of divergence in competitiveness and the formation of external imbalances between the euro area member states, because accelerating house prices give rise to a boom in private consumption and import demand (Aizenman and Jinjarak (2009)). House price dynamics influence the performance of the financial system through their impact on the profitability and soundness of financial institutions. Understanding this behaviour is of utmost significance for policymakers.

The institutional conditions in housing and mortgage markets are sub- 
stantially different across euro area member states (ECB (2009)). In the development of real house prices and their spillovers to the real economy, these structural features play a crucial role. For example, Almeida et al. (2006) have reported evidence that the sensitivity of house prices and mortgage borrowings to income shocks is higher in countries with higher loan-to-value ratios. Ludwig and Sløk (2004) and Carroll et al. (2006) have emphasized that the long-run responsiveness of consumption to permanent changes in housing wealth is higher for countries with a market-based than for countries with a bank-based financial system. According to Catte et al. (2004), strong impacts of real house prices on consumption can be detected especially in countries that have large, efficient and responsive mortgage markets. See also Calza et al. (2009). A high degree of mortgage market completeness, i.e., the extent to which the market is able to offer a variety of products and to serve a broad range of potential borrowers is also important. The most crucial element in this regard is the extent to which the markets provide opportunities for housing equity withdrawal, that is, the magnitude to which the household sector can extract liquidity from the housing market. The response of real house prices to macroeconomic conditions as well as their impact on private consumption and residential investment tends to be larger if a favorable tax treatment of mortgage interest encourages the leveraging of housing equity. Moreover, tax reliefs and subsidies, especially in favor of home ownership, can affect the development in the housing sector, and income tax systems appear to be conducive to house price volatility (van den Noord (2005)).

The importance of housing markets for the real economic performance as well as devastating effects of the housing busts require reliable tools for timely prediction the housing price bubbles. The aim of this paper is to design an early warning system in order to predict the bursts of the house price bubbles. Our data set covers 12 OECD countries (Australia, Canada, France, Germany, Italy, Japan, Netherlands, Spain, Sweden, Switzerland, UK, and the USA) and the time period 1st quarter 1969 - 4th quarter 2009.

The paper is structured as follows. Section 2 describes the method of deriving of a bubble chronology. Section 3, introduces three approaches signalling approach, logit and probit models - which are used for the prediction of the house price bubbles. Section 4 compares the predictive accuracy of these three alternative approaches. Finally, section 5 concludes. 


\section{Bubble chronology}

Obtaining a bubble chronology is not a trivial task. Because the bubble is not directly observable, it is not easy to distinguish between the growth of the house prices supported by the fundamental factors and that caused by the speculative expectations. We need to separate somehow the two effects in order to extract the speculative component.

In order to do this we propose here the following algorithm. We apply two alternative techniques: one based on estimating the deviations from the fundamental values and another one based on the deviations from the trend regardless of the fundamentals. The use of both techniques can be justified as follows. The speculative bubbles are the periods, when the house prices are higher than their fundamental values, that is, the house prices supported by the fundamentals. However, not each positive deviation from fundamental values can be treated as a speculative bubble, for these deviation might be too short and rather minor. Therefore, this chronology must be compared with that showing the periods, when the prices are above the trend. The final chronology is the one confirmed by both these techniques. Let us consider our algorithm in more details.

First, the real house prices are regressed on a set of the fundamental factors. As fundamental factors the following variables were used: 1) real GDP per capita approximating the disposable income; 2) population size; 3) urbanization, or share of the urban population in the total population; and 4) the own lag of the dependent variable, given the strong time persistance of the house prices (for description of the variables and data sources see Table 1). All these variables should positively affect the house prices. The higher income and population imply that more people need and can afford for the new or existing housing units. The urbanization is expected to have a negative effect on the house prices, since when urbanization is low, it might imply that the more people would migrate from the rural to the urban areas creating an upward pressure on the price of housing. The regression was estimated in levels for each country separately ${ }^{1}$ :

$$
r h p i_{i t}=\alpha_{0}+\alpha_{1} r h p i_{i, t-1}+\alpha_{2} r g d p_{-} p c_{i t}+\alpha_{3} p_{o p} p_{i t}+\alpha_{4} u r b a n i z_{i t}+\varepsilon_{i t}
$$

where $r h p i_{i t}$ is the logarithm of the real house price in country $i$ in period $t$; $r g d p_{-} p c_{i t}$ is the real per-capita GDP; pop $_{i t}$ is the population; and urbanizit

\footnotetext{
${ }^{1}$ In order to save space we do not report here the estimation results. However, they are avaiable upon request.
} 
is the urbanization rate. All other variables, except for urbanization, are also expressed in logs. The data are quarterly and cover at most the period 1970q1-2009q4. The fundamental real house price is defined then as:

$$
\overline{r h p i_{i t}}=\widehat{\alpha_{0}}+\widehat{\alpha_{1}} r h p i_{i, t-1}+\widehat{\alpha_{2}} r g d p_{-} p c_{i t}+\widehat{\alpha_{3}} p o p_{i t}+\widehat{\alpha_{4}} u r b a n i z_{i t}
$$

The positive deviations of the actual values from the fundamental values are treated as the potential speculative bubbles. In addition, since these deviations are sometimes too volatile, they are smoothed using a spline a regression.

Second, following Mendoza and Terrones (2008) we identified the house price booms (which are not necessarily bubbles) using the Hodrick-Prescott filter applied to the log of the real house prices and different thresholds determining the intensity of the house price growth:

$$
\text { cycle }_{i t}=\text { rhpi }_{i t}-\text { trend }_{i t}>\phi \sigma_{i}^{c}
$$

where trend $_{i t}$ is the Hodrick-Prescott trend obtained from the actual real house prices; $\phi$ is the boom threshold factor, determining the growth intensity, and $\sigma_{i}^{c}$ is the standard deviation of the cyclical component in country $i$, cycle $_{i t}$. Notice that the standard deviations are country specific. When the cyclical component is higher than the predefined threshold, then it is treated as a boom. Various values of the boom threshold factor were tested and the optimal threshold was chosen as the one providing the higher concordance between the deviations from fundamental values and booms.

Finally, the fundamental and boom approach are taken together to produce the speculative bubble chronology. The speculative bubble is thought to occur only when two conditions are met: 1) the smoothed deviation from the fundamental values is positive and higher than 0.5 standard deviation of the deviations and 2) it coincides or partly overlaps with a house price boom. The resulting chronology is shown in Figure 1, which plots the log of the real house prices against the periods that we identified as the speculative bubbles. In addition, the precise dates of speculative bubbles are presented in Table 3.

The average durations of the speculative bubbles are reported in Table 4 . The longest speculative house price bubbles are observed in Japan, UK, and USA: 18, 14.3, and 14 quarters, respectively. The bubbles are the shortest in the Netherlands and Sweden: 5 and 5.5 quarters, correspondingly. 


\section{Prediction of bubbles}

\subsection{Signalling approach}

The first method used here in order to detect and predict the speculative bubbles is the signalling approach. This method implies that for each relevant indicator of the bubble there exists a certain critical value, trespassing of which may be considered as an signal of an approaching or ongoing bubble.

We consider the following variables as the relevant ones, that is, as the variables, which might be useful for predicting the speculative bubbles: nominal and real money market rate, money supply, nominal and real money supply growth, spread, real effective exchange rate, rent, house price - to income ratio, house price - to - rent ratio, investment rate, nominal and real private lending ratio, general government balance - to - GDP ratio as well as growth rate of real per-capita GDP.

The algorithm is as follows. First, each of the above variables is smoothed using the Hodrick-Prescott filter separately for each country. Second, the smoothed series are standardized by dividing them by the country-specific standard deviations. Third, the smoothed and standardized variables are stacked over each other to build a panel. Fourth, a grid of potential critical values, or thresholds, is set comprising the values between 0.2 and 3 with a step equal to 0.2 . Thus, 15 possible thresholds are examined. The variable is said to send a signal of bubble when it exceeds a threshold. For each threshold, the accuracy of detecting the bubbles is evaluated by adding up the share of correctly identified bubbles in the total duration of bubbles and the share of correctly identified episodes of no bubbles in the total duration of nobubble periods. It is clear that both measures move in the opposite directions. The higher the threshold the less bubble periods are identified, however, the less false alarms (signals of bubbles when no bubbles take place) are produced. Therefore, the maximum of this measure corresponds to striking a balance between correctly identifying the bubbles and sending less false alarms. Formally, this accuracy coefficient can be defined as follows:

$$
Z_{i}^{\tau}=\frac{A}{A+C}+\frac{D}{B+D}
$$

where $\tau$ is the threshold $(\tau=0.2,0.4, \ldots, 3)$; $\mathrm{i}$ is the variable index; $A, B$, $C$, and $D$ are defined in the following table: 


\begin{tabular}{l|cc}
\hline & Bubble & No bubble \\
\hline Signal & A & B \\
No signal & C & D \\
\hline
\end{tabular}

This measure is similar to the signal-to-noise ratio. We decided to add and not to divide the left and right terms, given that at high $\tau$ values no false alarms are produced and hence $D=0$.

From 15 different threshold values, $\tau$, the optimal value is selected such that $Z_{i}^{\tau}$ is maximized over $\tau$. These optimal values together with the accuracy coefficient, $Z_{i}^{\tau}$, are reported in Table 2 .

For this optimal threshold an individual signal series is produced for each variable. This signal series is equal to 1 , when the smoothed and standardized variable exceeds the threshold, and to 0 , otherwise.

From the individual signal series a composite signal series is computed as a weighted average. The weights are the squared accuracy coefficients, $\left(Z_{i}^{\tau}\right)^{2}$. They are squared in order to give even more weight to the variables that are more useful in predicting the speculative bubbles. The composite signal series is depicted in Figure 2 as the continuous black line. The gray shaded areas represent the periods of speculative bubbles.

\subsection{Logit/probit approach}

Logit/probit approach is an alternative technique of detecting and predicting the speculative bubbles. It allows determining the sign and significance of the influence of each of the relevant variables in predicting the speculative bubbles. In general, these two - logit and probit - techniques can be formulated as:

$$
\operatorname{Pr}\left(R_{i t}=1 \mid X_{i t}\right)=F\left(X_{i t} \beta+\varepsilon_{i t}\right)
$$

where $\operatorname{Pr}(\bullet)$ is the conditional probability of the speculative bubble; is the reference chronology of the speculative bubbles; $X_{i t}$ is the set of relevant variables listed in the section on the signalling approach plus the property tax rate; $F(\bullet)$ is some cumulative probability function (logistic or Gaussian one); $\varepsilon_{i t}$ is the disturbance term. The difference between the logit and probit models lies in the corresponding probability functions.

Here we apply the logit and probit approaches to the panel data. The fixed effects were accounted for by subtracting from all the variables, except for the dummy ones, their within-group means. Then, the pooled logit and probit estimation was applied to these demeaned data. 
Figures 3 and 4 compare the model-derived probabilities of speculative bubbles based on the logit and probit models (continuous black line) to the binary reference chronology (gray shaded areas). Both models produce similar results and allow capturing the bubbles quite accurately.

\section{Evaluating the accuracy of predicting the bubbles}

The accuracy of the alternative prediction approaches presented above can be evaluated using the Quadratic Probability Score (QPS) measure, which is defined as follows:

$$
Q P S=\frac{1}{T} \sum_{t=1}^{T}\left(R_{i t}-P_{i t}^{j}\right)^{2}
$$

where $P_{i t}^{j}$ is the $j$-th alternative model-derived probabilities of speculative bubbles (based on signalling approach as well as on logit and probit models). QPS varies between 0 and 1 . The lower the QPS the more precise are the predictions of the speculative bubbles.

The QPS computed for all three models is reported in Table 5. It can be seen that the signalling approach is much less accurate than the logit and probit ones. The latter two produce practically identical results in terms of the predictive power of the speculative bubbles. The forecasting accuracy of the logit and probit models is relatively high. This implies that they can be used as an early warning system in order to predict the future speculative bubbles in the housing markets.

\section{Conclusion}

In this paper, we constructed the country-specific chronologies of the house price bubbles for 12 OECD countries (Australia, Canada, France, Germany, Italy, Japan, Netherlands, Spain, Sweden, Switzerland, UK, and the USA) over the period 1969q1-2009q4. These chronologies were obtained using a combination of a fundamental and filter approaches. The resulting speculative bubble chronology is the one that provides the highest concordance between these two techniques. 
In addition, we suggested an early warning system based on three alternative approaches: signalling approach, logit and probit models. The predictive accuracy of these three approaches was tested against the speculative bubble chronologies we determined in the first step. It was shown that the latter two models allow much more accurate predictions of the house price bubbles than the signalling approach. The prediction accuracy of the logit and probit models is high enough to make them useful in forecasting the future speculative bubbles in housing market.

Thus, our method can be considered as an important tool to be used by the policymakers in their attempts to timely detect the house price bubbles and attenuate their devastating effects on the domestic and world economy.

\section{References}

Adrian, T. and H. Shin (2008). Liquidity, monetary policy, and financial cycles. Current Issues in Economics and Finance (Jan).

Agnello, L. and L. Schuknecht (2009). Booms and busts in housing markets - Determinants and implications. ECB Working Paper Series 1071.

Aizenman, J. and Y. Jinjarak (2009). Current account patterns and national real estate markets. Journal of Urban Economics 66 (2), 75-89.

Almeida, H., M. Campello, and C. Liu (2006). The financial accelerator: Evidence from the international housing markets. Review of Finance 10(3), $321-352$.

Aoki, K., J. Proudman, and G. Vlieghe (2004). House prices, consumption, and monetary policy: A financial accelerator approach. Journal of Financial Intermediation 13(4), 414-435.

Bernanke, B. S., M. Gertler, and S. Gilchrist (1999). The financial accelerator in a quantitative business cycle framework. In J. B. Taylor and M. Woodford (Eds.), Handbook of Macroeconomics, Volume 1 of Handbook of Macroeconomics, Chapter 21, pp. 1341-1393. Elsevier.

Borio, C. and P. Lowe (2002). Asset prices, financial and monetary stability: exploring the nexus. BIS Working Papers N 114. 
Calza, A., T. Monacelli, and L. Stracca (2009). Housing finance and monetary policy. ECB Working Paper Series 1069.

Carroll, C. D., M. Otsuka, and J. Slačálek (2006). How large is the housing wealth effect? A new approach. NBER Working Papers 12746.

Case, K. E., J. M. Quigley, and R. J. Shiller (2005). Comparing wealth effects: The stock market versus the housing market. The B.E. Journal of Macroeconomics (1).

Catte, P., N. Girouard, R. Price, and C. André (2004). Housing markets, wealth and the business cycle. OECD Economics Department Working Papers 394.

Congdon, T. (2005). Money and asset prices in boom and bust. Institute of Economic Affairs, IEA Hobart Paper 153.

Dreger, C. and H.-E. Reimers (2009). The role of asset markets for private consumption: Evidence from paneleconometric models. Discussion Papers of DIW Berlin 872.

Dreger, C. and J. Wolters (2009). M3 velocity and asset prices in the euro area. Empirica 36, 51-63.

ECB (2009). Housing finance in the Euro Area. Structural Issues Report.

Goodhart, C. and B. Hofmann (2008). House prices, money, credit and the macroeconomy. Oxford Review of Economic Policy 24, 180-205.

Holly, S., H. Pesaran, and T. Yamagata (2010). Spatial and temporal diffusion of house prices in the UK.

Iacoviello, M. (2005). House prices, borrowing constraints, and monetary policy in the business cycle. American Economic Review 95(3), 739-764.

Iacoviello, M. and S. Neri (2010). Housing market spillovers: Evidence from an estimated DSGE model. American Economic Journal: Macroeconomics 2(2), 125-64.

IMF (2008). The changing housing cycle and the implications for monetary policy. World Economic Outlook. 
Kholodilin, K. A., J.-O. Menz, and B. Siliverstovs (2010). What drives housing prices down? Evidence from an international panel. Jahrbücher für Nationalökonomie und Statistik 230(1), 59-76.

Ludwig, A. and T. Sløk (2004). The relationship between stock prices, house prices and consumption in OECD countries. The B.E. Journal of Macroeconomics (1).

Mendoza, E. G. and M. E. Terrones (2008). An anatomy of credit booms: Evidence from macro aggregates and micro data. NBER Working Papers 14049 .

Muellbauer, J. (2008). Housing, credit and consumer expenditure. C.E.P.R. Discussion Papers 6782.

Muellbauer, J. and A. Murphy (2008). Housing markets and the economy: The assessment. Oxford Review of Economic Policy 24 (1), 1-33.

Poterba, J. M. (2000). Stock market wealth and consumption. Journal of Economic Perspectives 14(2), 99-118.

Setzer, R., P. van den Noord, and G. B. Wolff (2010). Heterogeneity in money holdings across Euro Area countries: The role of housing. European Economy - Economic Papers 407.

Tsatsaronis, K. and H. Zhu (2004). What drives housing price dynamics: Cross-country evidence. BIS Quarterly Review, 65-78.

van den Noord, P. (2005). Tax incentives and house price volatility in the Euro Area: Theory and evidence. Economie Internationale (1Q), 29-45. 


\section{Appendix}

Table 1: Data description

\begin{tabular}{l|ll}
\hline Variable & Definition & Source \\
\hline House price index & & NiGEM \\
Noney supply & & Datastream \\
Nominal and real GDP & & Datastream \\
GDP deflator & 3-month interest rate & Datastream \\
Long-term interest rate & Datastream \\
Short-term interest rate & & Datastream \\
Lending to households & & Datastream \\
Nominal exchange rate & & Datastream \\
Real effective exchange rate & & Datastream \\
Population & & Datastream \\
Urban population & Global Insight \\
Rent index & House price index / GDP deflator & Global Insight \\
Real house price index & House price / GDP & Global Insight \\
House price-income index & House price / Rent & OECD \\
House price-rent index & Nominal investment / Nominal GDP & OECD \\
Invesment rate & GDP / Population & own calculation \\
Real per-capita GDP & Urban population / Population & own calculation \\
Urbanization & Lending / BIP & own calculation \\
Lending rate & Long-term - Short-term interest rate & own calculation \\
Spread & General government balance / GDP & OECD \\
General government balance-to-GDP ration \\
$\begin{array}{l}\text { Property taxation } \\
\text { Mortgage market deregulation }\end{array}$ & Property tax revenues / GDP & OECD \\
\hline
\end{tabular}


Table 2: Optimal thresholds for signalling approach

\begin{tabular}{l|cc}
\hline Variable & $\begin{array}{c}\text { Optimal } \\
\text { threshold }\end{array}$ & $\begin{array}{c}\text { Accuracy } \\
\text { coefficient }\end{array}$ \\
\hline Money market rate & 0.4 & 1.25 \\
Real effective exchange rate & 1.0 & 1.38 \\
Rent & 0.4 & 1.17 \\
House-price-to-income ratio & 1.0 & 1.44 \\
House-price-to-rent ratio & 1.0 & 1.48 \\
Investment-to-GDP ratio & 1.0 & 1.47 \\
Lending-to-GDP ratio & 1.0 & 1.23 \\
Spread & 3.0 & 1.01 \\
Money supply & 0.2 & 1.12 \\
General government balancetoGDP ratio & 1.4 & 1.02 \\
Real money market rate & 0.4 & 1.24 \\
Money supply growth & 0.8 & 1.48 \\
Real money supply growth & 1.2 & 1.4 \\
Nominal lending growth & 0.6 & 1.39 \\
Real lending growth & 1.0 & 1.39 \\
Growth rate of real per-capita GDP & 0.2 & 1.34 \\
\hline
\end{tabular}


Table 3: Chronology of the speculative bubbles of house prices

\begin{tabular}{|c|c|c|c|}
\hline $\begin{array}{l}\text { Beginning } \\
\text { of bubble }\end{array}$ & $\begin{array}{c}\text { End } \\
\text { of bubble }\end{array}$ & $\begin{array}{l}\text { Beginning } \\
\text { of bubble }\end{array}$ & $\begin{array}{c}\text { End } \\
\text { of bubble }\end{array}$ \\
\hline \multicolumn{2}{|c|}{ Australia } & \multicolumn{2}{|c|}{ Netherlands } \\
\hline 1988q1 & $1989 \mathrm{q} 2$ & - & $1978 \mathrm{q} 2$ \\
\hline $2002 q 3$ & $2004 q 1$ & \multicolumn{2}{|c|}{ Portugal } \\
\hline $2006 q 4$ & - & $1998 \mathrm{q} 4$ & 2001q1 \\
\hline \multicolumn{2}{|c|}{ Canada } & \multicolumn{2}{|c|}{ Spain } \\
\hline $1972 q 3$ & $1974 q 3$ & $1973 q 1$ & $1974 q 2$ \\
\hline $1980 \mathrm{q} 2$ & $1981 q 2$ & $1976 \mathrm{q} 3$ & $1978 \mathrm{q} 2$ \\
\hline 1986q1 & $1989 q 4$ & $1986 \mathrm{q} 2$ & 1991q2 \\
\hline 2006q1 & $2007 q 1$ & $2003 \mathrm{q} 1$ & $2007 q 1$ \\
\hline \multicolumn{2}{|c|}{ France } & \multicolumn{2}{|c|}{ Sweden } \\
\hline $1979 q 4$ & $1980 \mathrm{q} 4$ & $1993 q 4$ & $1994 q 2$ \\
\hline $2002 q 4$ & $2006 \mathrm{q} 2$ & $2005 q 3$ & $2007 \mathrm{q} 2$ \\
\hline \multicolumn{2}{|c|}{ Germany } & \multicolumn{2}{|c|}{ Switzerland } \\
\hline 1992q4 & $1994 q 3$ & - & $1973 \mathrm{q} 2$ \\
\hline Italy & & 1987q1 & $1989 \mathrm{q} 3$ \\
\hline — & 1981q4 & \multicolumn{2}{|c|}{ UK } \\
\hline $1988 \mathrm{q} 3$ & 1992q1 & 1971q4 & $1973 q 3$ \\
\hline \multicolumn{2}{|c|}{ Japan } & $1985 q 4$ & $1989 \mathrm{q} 1$ \\
\hline \multirow[t]{4}{*}{ 1986q2 } & $1990 \mathrm{q} 3$ & $2002 q 2$ & $2007 q 2$ \\
\hline & & \multicolumn{2}{|c|}{ USA } \\
\hline & & 1977q1 & $1978 q 4$ \\
\hline & & $2001 q 2$ & 2006q1 \\
\hline
\end{tabular}


Table 4: Descriptive statistics of the house price speculative bubbles

\begin{tabular}{l|ccc}
\hline Country & $\begin{array}{c}\text { Number of } \\
\text { bubbles }\end{array}$ & $\begin{array}{c}\text { Average } \\
\text { duration of } \\
\text { bubble, } \\
\text { quarters }\end{array}$ & $\begin{array}{c}\text { Estimation } \\
\text { sample }\end{array}$ \\
\hline Australia & 3 & 8.7 & $1986 \mathrm{q} 3-2009 \mathrm{q} 4$ \\
Canada & 4 & 8.8 & $1970 \mathrm{q} 2-2009 \mathrm{q} 4$ \\
France & 2 & 10.0 & $1970 \mathrm{q} 2-2009 \mathrm{q} 4$ \\
Germany & 1 & 8.0 & $1991 \mathrm{q} 2-2009 \mathrm{q} 4$ \\
Italy & 2 & 9.0 & $1981 \mathrm{q} 2-2009 \mathrm{q} 4$ \\
Japan & 1 & 18.0 & $1969 \mathrm{q} 4-2009 \mathrm{q} 4$ \\
Netherlands & 1 & 5.0 & $1977 \mathrm{q} 2-2009 \mathrm{q} 4$ \\
Portugal & 1 & 10.0 & $1995 \mathrm{q} 2-2009 \mathrm{q} 4$ \\
Spain & 4 & 13.0 & $1971 \mathrm{q} 2-2009 \mathrm{q} 4$ \\
Sweden & 2 & 5.5 & $1993 \mathrm{q} 2-2009 \mathrm{q} 4$ \\
Switzerland & 2 & 12.0 & $1970 \mathrm{q} 2-2002 \mathrm{q} 3$ \\
UK & 3 & 14.3 & $1971 \mathrm{q} 1-2009 \mathrm{q} 4$ \\
USA & 2 & 14.0 & $1975 \mathrm{q} 2-2009 \mathrm{q} 4$ \\
\hline
\end{tabular}

Table 5: Prediction accuracy of the alternative models

\begin{tabular}{l|c}
\hline Model & QPS \\
\hline Signalling & 0.278 \\
Logit & 0.074 \\
Probit & 0.075 \\
\hline
\end{tabular}


Figure 1: Chronology of the house price bubbles
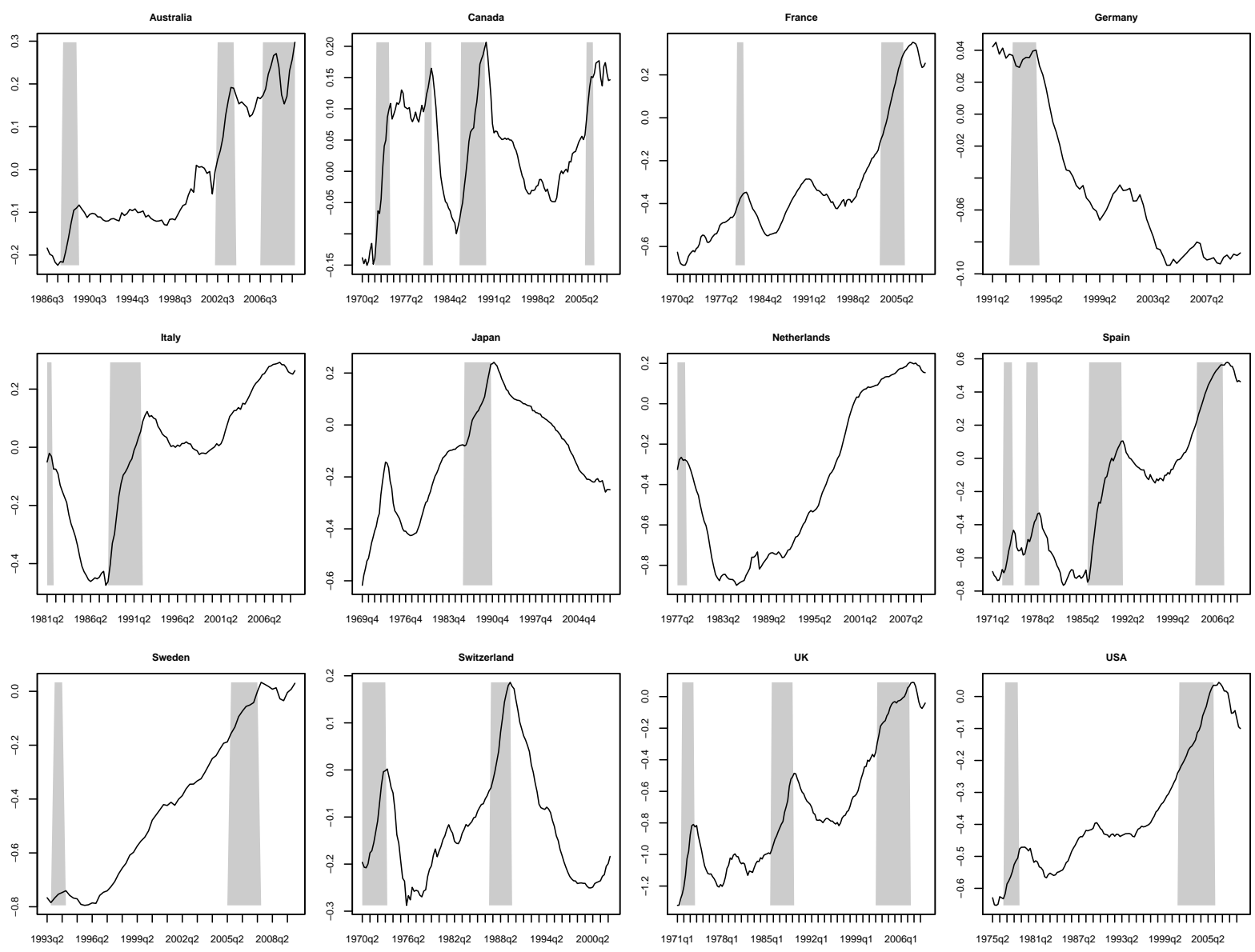
Figure 2: House price bubbles vs. bubble prediction by signalling approach
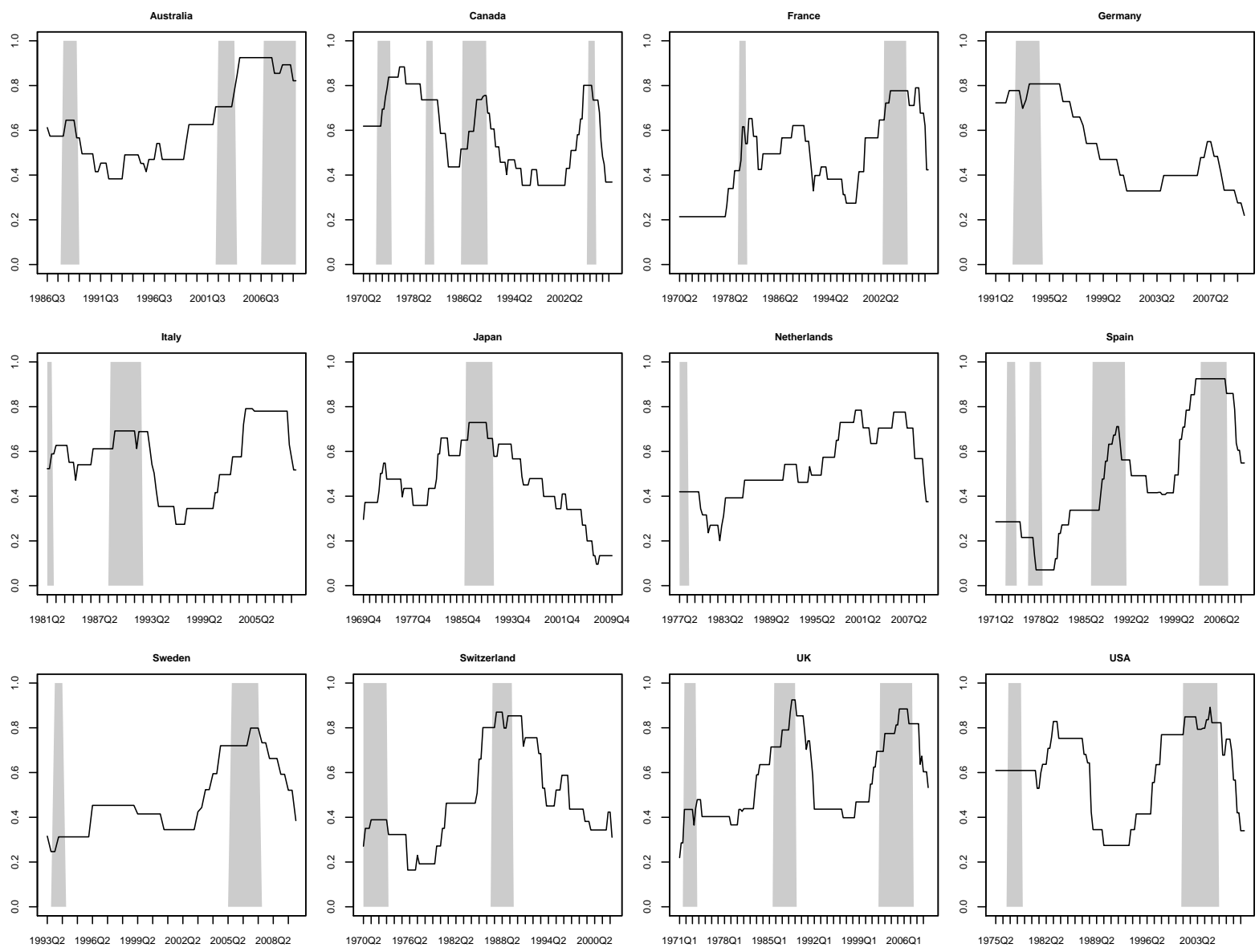
Figure 3: House price bubbles vs. bubble prediction by logit approach
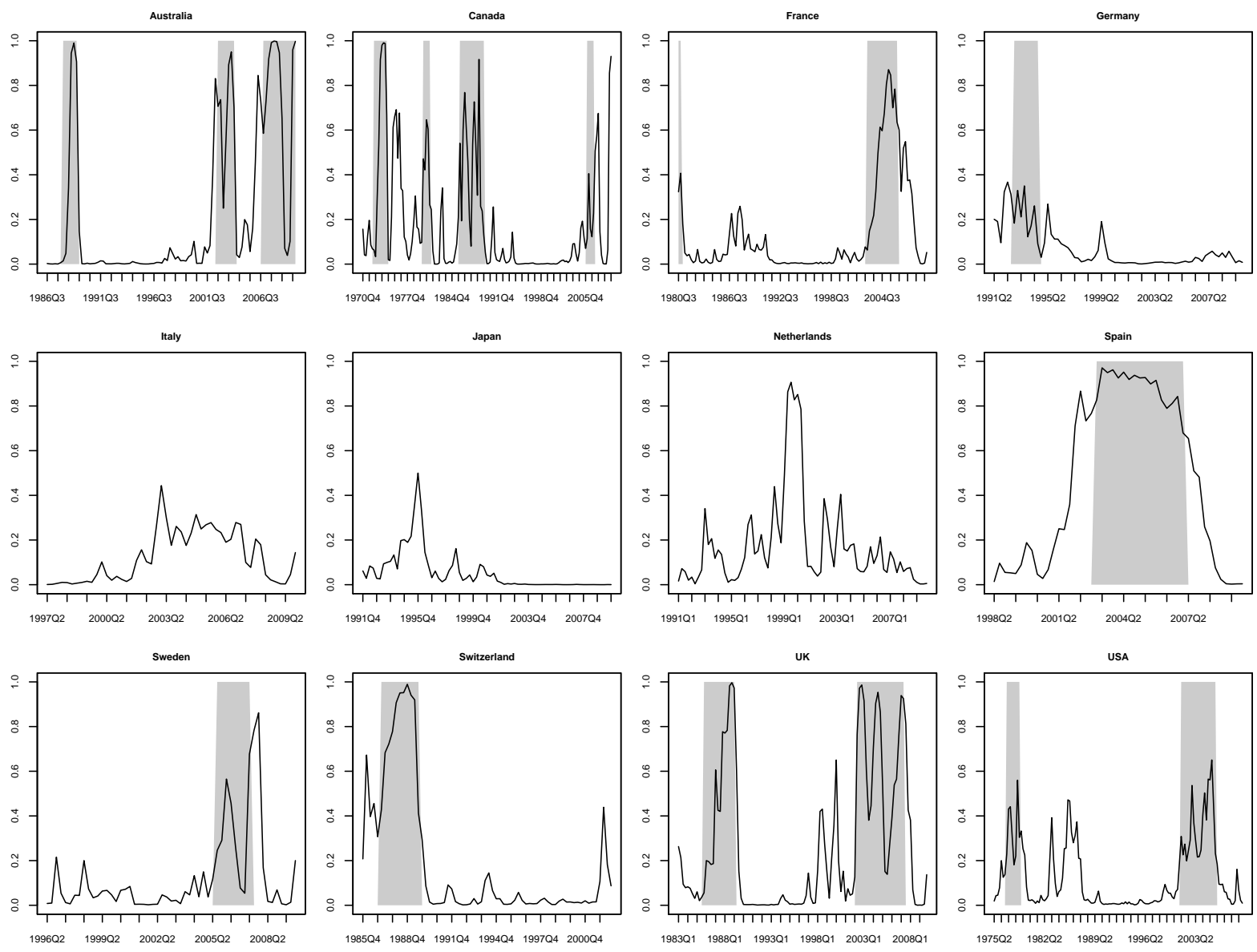
Figure 4: House price bubbles vs. bubble prediction by probit approach
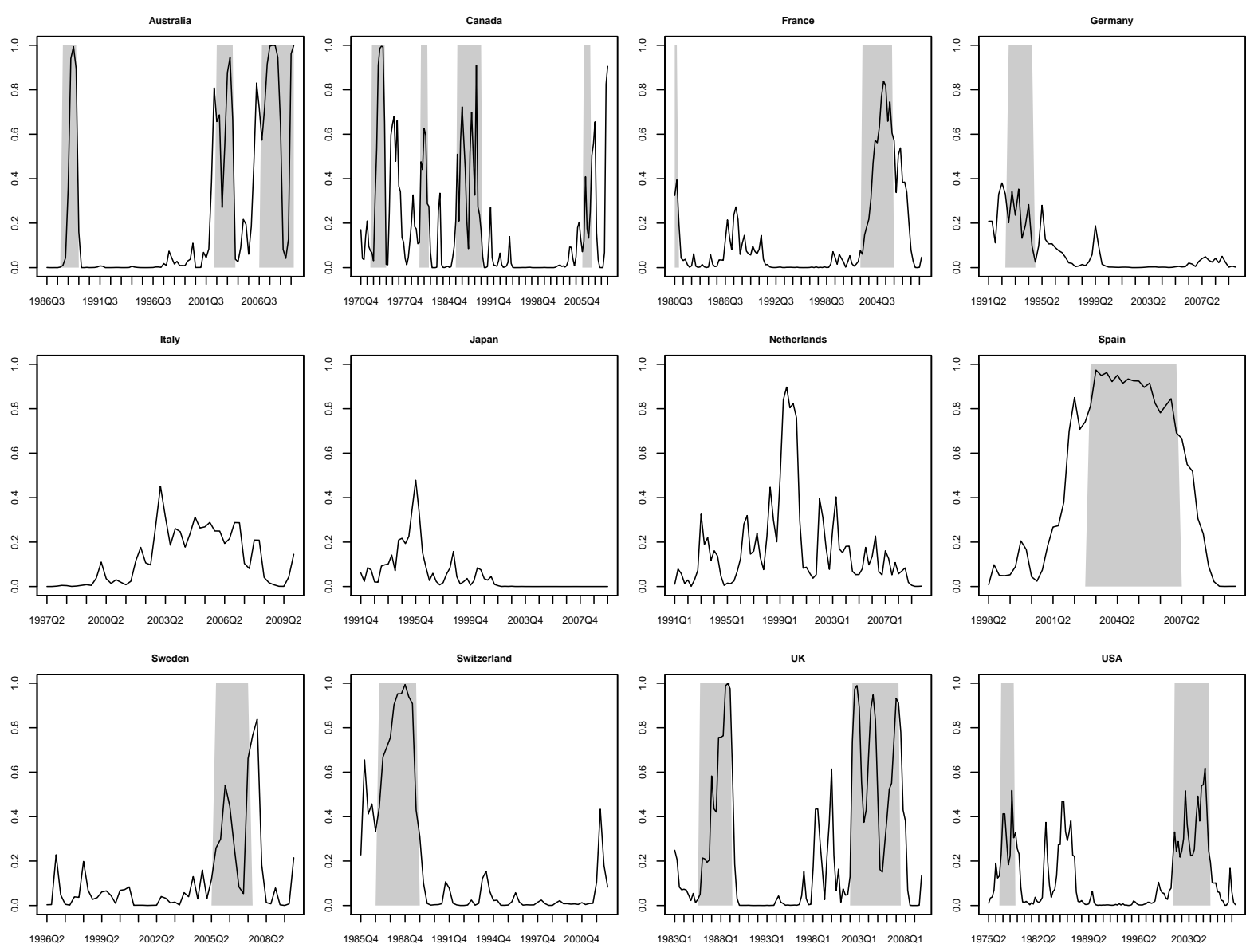